\title{
Tax Treatment of Education Expenses: Perspectives from Normative Theory
}

\author{
Clifford Gross $\dagger$
}

Current law makes it difficult, sometimes impossible, for most federal taxpayers to deduct the cost of borrowing for education. ${ }^{1}$ Prior to the Tax Reform Act of 1986, ${ }^{2}$ individual taxpayers could deduct interest expenses against ordinary income when the interest was paid. This rule resulted in a satisfactory matching of the interest cost of borrowing for education with the return on that investment. ${ }^{3}$ Currently, however, $\S 163(\mathrm{~h})$ of the Internal Revenue Code of 1986 allows only those taxpayers who secure education loans with their homes to deduct the interest payments. ${ }^{4}$ Those who can use their homes as collateral receive a federal subsidy of their education expenses while non-homeowners do not. As this comment will show, the present tax treatment of education interest expenses is inconsistent both with sound normative principles of taxation and with the legislative aims underlying the 1986 Code.

More particulary, insofar as a portion of education expenses represents an investment in human capital rather than a pure purchase of cultural enrichment, those investment expenses should be amortized over the working life of the taxpayer and should provide the taxpayer deductions for the recovery of capital. Applying this normative principle to all education expenses would be an impractical policy, for it would both create overwhelming administrative problems and substantially diminish tax revenues. However, this comment will argue that the difficulty in extending deductions

† B.S. 1985, Yale University; J.D. Candidate 1988, The University of Chicago.

- Some education costs can be deducted as business expenses under Treasury Regulation $§ 1.162-5$. However, this regulation specifically disallows most education expenses because they "constitute an inseparable aggregate of personal and capital expenses and, therefore, are not deductible as ordinary and necessary business expenses." Treas.Reg. \$ 1.162$5(b)(1)$.

${ }_{2}$ Tax Reform Act of 1986, Pub.L.No. 99-514, - Stat. --, codified at 26 U.S.C. $\S 1$ et seq. (1986)("1986 Act").

${ }^{3}$ Internal Revenue Code of $1954 \S 163(a)$, Pub.L.No. 83-591, 68A Stat. 3 (1954).

- Internal Revenue Code of $1986 \S 163(\mathrm{~h}), 26$ U.S.C. $\S 163(\mathrm{~h})$ (1986). The Internal Revenue Code of 1986, including amendments introduced by the Revenue Act of 1987 , will be referred to as the "1986 Code." All further citations are to specific sections of the Internal Revenue Code ("I.R.C."). 
to various other education expenses should not preclude the deductibility of interest on education loans.

Section I examines the current treatment of education interest expenses under $\S 163(\mathrm{~h})$, demonstrating that it fails to effectuate the congressional intent behind the 1986 Act and does not achieve tax neutrality in education investment decisions. In addition, section I shows that $\S 163(\mathrm{~h})$ generates a tax expenditure for homeowners which is unjustifiably linked to the historical homeownership tax preference. ${ }^{5}$ Section II explains the normative principles underlying personal income taxation. Normative analysis provides a theoretical benchmark with which to analyze $\S 163(\mathrm{~h})$ and shows that education costs are properly divided into investment and consumption portions, and that the former should be treated as a deductible expense. Relying on this normative analysis, section III proposes a legislative solution to correct the fundamental flaws of $\S$ 163(h) with respect to educational expenses. This Comment concludes that education interest expenses should be available as a deduction to all taxpayers.

\section{Current Treatment of Educational Interest Expenses UNDER § 163(H)}

The central purpose of the 1986 Act was to reduce the influence of tax bias in taxpayers' economic decisions. To that end, Congress eliminated the consumer or personal interest deduction of $\S 163(\mathrm{a})$ of the 1954 Code. Interest expenses for education loans fell within the parameters of $\S 163(\mathrm{a})$. With $\S 163(\mathrm{~h})$, the 1986 Act repealed $\S 163(\mathrm{a})$ and the personal interest deduction. As amended by the Revenue Act of $1987, \S 163(\mathrm{~h})$ denies taxpayers any personal interest deduction, including education interest, unless the interest is paid on a loan secured by the taxpayer's residence. ${ }^{6}$

5 This Comment will use the terms tax expenditure and tax preference synonymously. In 1967, Professor Stanley Surrey introduced the expression "tax expenditures" to convey the idea that governmental action through the tax laws may be a functional substitute for direct expenditures. Stanley S. Surrey, Pathways to Tax Reform 6-7 (1973). The primary difference between tax expenditures and direct expenditures is that the former reduce receipts, while the latter must enter the budget as outlays thus involving distinct political processes and considerations.

${ }^{B}$ Section 163(h) provides that "[i]n the case of a taxpayer other than a corporation, no deduction shall be allowed under this chapter for personal interest paid or accrued during the taxable year." I.R.C. $\$ 163(\mathrm{~h})(1)$. Homeowners who pay interest on loans secured by their homes are provided with exceptions to this general prohibition. See $\S \S 163(\mathrm{~h})(2)-(5)$. 
A. Legislative Intent of $\S 163(\mathrm{~h})$ and the 1986 Act

An outline of Congress' intent in reforming the tax laws provides a foundation for analysis of the operation and results of $\S$ 163(h). On October 22, 1986, the President signed the Tax Reform Act of 1986. Reflecting years of political and academic debate, the 1986 Act restructured the American system of taxation. With respect to the individual income tax, the 1986 Act's primarily sought to reshape the tax law to encourage savings and investment rather than consumption, ${ }^{7}$ a focus preserved in the Revenue Act of $1987 .{ }^{8}$ Many politicians, academics, and tax practitioners felt the Tax Code of 1954, through its complex deductions and credits, encouraged taxpayers ( 1 ) to make investment and consumption decisions according to their tax consequences rather than on the nontax economic merits of such decisions, and (2) to consume rather than save or invest. The personal interest deduction allowed in $\S$ 163(a) of the 1954 Code reflects these problems: the deduction encouraged taxpayers to consume and to support their increased consumption by assuming debt. Essentially, the 1954 Code supported increased consumption through tax expenditures. ${ }^{9}$

Congress perceived the policies embodied in the 1954 Code to be hampering the nation's economy and reacted by repealing the personal interest deduction found in $\S 163$ (a) and amending many other provisions. These modifications were intended to reduce the complexity, increase the fairness, and heighten the efficiency of the federal income tax system. Although it is often difficult to determine whether a unified intent animated the legislative process, one can safely assume that the central objective of the reform legislation was to reduce the perceived tax-bias affecting taxpayers' economic decisions. ${ }^{10}$

The legislative history does not make clear why Congress allowed homeowners to retain the deduction for personal interest on

Teneral Explanation of the Tax Reform Act of 1986, 74 Fed.Tax Rep. (CCH) No.19 at 9 (1987) ("The Blue Book"). Congress prepared The Blue Book after the passage of the 1986 Act in order to provide insight into the purposes of the Act. Although courts occasionally have cited The Blue Book, it is purely intended as explanatory material and does not have the same legal force as precedent or legislative history.

Omnibus Budget Reconciliation Act of 1987, H.R.Rep.No. 100-391, 100th Cong., 1st Sess. 1031-34 (1987); Omnibus Budget Reconciliation Act of 1987, Conf.Rep.No. 100-495, 100th Cong., 1st Sess. 916-17 (1987).

- See Allaire Urban Karzon, Tax Expenditures and Tax Reform, 38 Vand.L.Rev. 1397, 1399 (1985), for a more complete discussion on how tax expenditures influence taxpayer behavior.

${ }^{10}$ See The Blue Book at 6 (cited in note 7). 
loans secured by their homes in addition to the deduction for home mortgage interest. Perhaps Congress wished to provide an added incentive to encourage homeownership. A second explanation is that homeowners, both through their own political power and through the real estate and banking lobbies, exerted political pressure for preferential treatment by Congress. ${ }^{11}$

The 1954 Code perceived education expenses as falling under the personal interest category of $\S 163(a)$, although education expenses arguably are more like savings or investment than consumption. Like the 1954 Code, the 1986 Act did not recognize the investment character of education expenses and eliminated the deduction for education loan interest along with other personal deductions. ${ }^{12}$ The 1987 amendments to $\S 163(\mathrm{~h})$ continued to assume that education is a personal consumption item and, hence, that any deduction granted for the interest expense of borrowing for education is a tax expenditure. ${ }^{13}$

\section{B. Current Operation of $\S 163(\mathrm{~h})$}

Section $163(\mathrm{~h})$ is a broad exclusionary provision which plainly states that "[i]n the case of a taxpayer other than a corporation, no deduction shall be allowed under this chapter for personal interest paid or accrued during the taxable year."14 The section thereby eliminates the deduction for interest-for example, credit card in-

"See Jeffrey H. Birnbaum and Alan S. Murray, Showdown at Gucci Gulch: Lawmakers, Lobbyists, and the Unlikely Triumph of Tax Reform 57, 111 (1987).

12 The 1986 Act also treated education and medical interest as personal interest but gave both special status by allowing such loans up to the fair market value of the residence securing them. I.R.C. $\$ 163(\mathrm{~h})(4)(B)$ and $(E)(1986)$. The 1986 Act has since been amended; current law imposes a $\$ 100,900$ limitation on the amount of deductible income.

${ }^{13}$ The 1987 amendments altered only the form of $\S 163(\mathrm{~h})$ and a few minor particulars. The Revenue Act of 1987 amended $\S 163(\mathrm{~h})$ by placing all personal interest deductions in $\S$ $163(h)(3)$. Section $163(h)(4)$ was eliminated and $\S 163(h)(5)$ was redesignated as $\S 163(\mathrm{~h})(4)$. Section $163(\mathrm{~h})(4)$ of the 1986 Act permitted borrowing for education if secured by a qualified residence up to the fair market value of such residence, while the 1987 amendments permit such borrowing only up to $\$ 100,000$. On the surface, the 1987 rule appears to be more restrictive. However, when one considers that $\$ 100,000$ is a high allowance for the majority of homeowning taxpayers and that the 1987 rule eliminates any restriction on the use of the borrowed money, the new rule appears more permissive in its application to most homeowning taxpayers.

it I.R.C. $\$ 163(\mathrm{~h})(1)$. This provision creates a potential loophole for the taxpayer who might consider incorporating to avoid losing the personal interest deduction. However, it is unlikely that many taxpayers will initiate such a costly and sophisticated process simply to retain this deduction. Most individuals tend to avoid the corporate form because of factors unrelated to $\S 163(\mathrm{~h})$ : for example, potentially higher marginal tax rates, the possible loss of other deductions such as the standard deduction for individual taxpayers, and the non-deductibility of certain personal expenses even if the taxpayer does incorporate. 
terest-incurred in the course of personal consumption.

Congress provided an exception to this general rule, however, for taxpayers who itemize ${ }^{15}$ and who borrow against homes they own. Section 163(h), as amended in 1987, allows homeowners ${ }^{16}$ to borrow in the form of a home equity loan for any purpose, including education, and then to deduct the subsequent interest payments when they are made. ${ }^{17}$ Deductions for these payments are allowed because they fit into one of the categories listed in $\S$ 163(h)(2), specifying forms of interest that are deductible because they are not deemed "personal."18

Section 163(h)(3) defines "qualified residence interest" as any interest paid by the taxpayer "on indebtedness which is secured by any property .... which .... is a qualified residence of the taxpayer." Since $\S 163(\mathrm{~h})$ applies only to loans secured with a "qualified residence," a taxpayer who seeks to use that $\S$ to obtain a deduction for interest on an educational loan-typically a recourse loan-could lose that residence if she defaults on the loan.

Section 163(h)(3), the deduction provision for homeowners, consists of two parts: (1) "acquisition indebtedness", 19 and (2) "home equity indebtedness,"20 both concepts introduced by the

${ }^{15}$ I.R.C. $\S 63(\mathrm{~d})$ states that "itemized deductions" include all deductions except: (1) deductions allowed in arriving at adjusted gross income under $\S 62$ (e.g., trade and business deductions), and (2) deductions under $\S 151$ for personal exemptions. Section 163(h) is available only to itemizers.

${ }^{16}$ Homeowner is defined for purposes of this comment as a person who owns a "qualified residence". "Qualified residence" is defined in amended $\S 163(\mathrm{~h})(3)(\mathrm{A})$ to mean (1) the taxpayer's principal residence within the meaning of $\S 1034$ and (2) one other residence, selected by the taxpayer, which is used as a residence as defined in $\S 280 \mathrm{~A}(\mathrm{~d})(1)$. Simply put, the taxpayer can deduct the interest expense of loans secured by any two residences owned by the taxpayer. A residence can be a house, a condominium, a co-op, a mobile home, and possibly a boat.

${ }_{17}$ Most individual taxpayers use the cash receipts and disbursements method of accounting for tax purposes and hence interest deductions under $\S 163(\mathrm{~h})$ would be deducted in the year when actually paid to the lending institution.

${ }^{18}$ The five categories specified in $\S 163(\mathrm{~h})(2)$ are:

(A) interest paid or accrued on indebtedness incurred or continued in connection with the conduct of a trade or business (other than the trade or business of performing services as an employee),

B) any investment interest (within the meaning of subsection (d)),

C) any interest which is taken into account under $\$ 469$ in computing income or loss from a passive activity of the taxpayer,

D) any qualified residence interest (within the meaning of paragraph (3)), and

E) any interest payable under $\S 6601$ on any unpaid portion of the tax imposed by $\S$ 2001 for the period during which an extension of time for payment of such tax is in effect under $\S 6163$ or 6166 .

${ }^{19}$ I.R.C. $\S 163(\mathrm{~h})(3)(\mathrm{A})(\mathrm{i})$.

${ }^{20}$ I.R.C. $\S 163(\mathrm{~h})(3)(\mathrm{A})(\mathrm{ii})$. 
1987 amendments. Acquisition indebtedness is defined in $\S$ $163(\mathrm{~h})(3)(\mathrm{B})$ as any indebtedness which "is incurred in acquiring, constructing, or substantially improving any qualified residence of the taxpayer, and . . . is secured by such residence."21 This restriction is tempered by a high limitation of $\$ 1,000,000$ of indebtedness that can support deductible interest. ${ }^{22}$ No ceiling on acquisition indebtedness was present in $\S 163(\mathrm{~h})$ of the 1986 Act. $^{23}$

"Home equity indebtedness," the second new element introduced by amended $\S 163(\mathrm{~h})(3)$, is defined as "any indebtedness (other than acquisition indebtedness) secured by a qualified residence". ${ }^{24}$ Home equity indebtedness can be used for any purpose, including education, and home equity indebtedness is subject to two limitations: (1) an overall limitation of $\$ 100,000,{ }^{25}$ and (2) "the fair market value of such qualified residence [securing such indebtedness], reduced by the amount of acquisition indebtedness with respect to such residence." ${ }^{26}$

Section 163(h) allows a taxpayer to deduct interest paid on education loans secured by either a principal or secondary residence. The interest is deductible if the aggregate amount of the principal borrowed does not exceed the difference between the qualified residence's fair market value and acquisition indebtedness. If the amount of borrowing exceeds $\$ 100,000$ then only a proportionate amount of interest will be deductible in that taxable

21 I.R.C. $\$ 163(\mathrm{~h})(3)(\mathrm{B})(\mathrm{i})$.

${ }^{22}$ See I.R.C. $\$ 163(\mathrm{~h})(3)(\mathrm{B})(\mathrm{ii)}$. Even though the $\$ 1,000,000$ ceiling appear high, it is notably the first attack on the homeowner interest deduction in the history of personal income taxation in the United States.

${ }^{23}$ For those taxpayers who secured education loans with their homes under $\S 163(\mathrm{~h})(4)$ of the 1986 Act, prior to October 13,1987, such borrowing is acquisition indebtedness under the amended Code. I.R.C. $\S 163(\mathrm{~h})(3)(\mathrm{D})(\mathrm{i})$. Any such indebtedness lowers the $\$ 1,000,000$ ceiling on acquisition indebtedness, I.R.C. $\S 163(\mathrm{~h})(3)(\mathrm{D})(\mathrm{ii})$, but the taxpayer may secure additional education loans up to the $\$ 100,000$ limit of home equity indebtedness without losing any interest deductions.

${ }^{24}$ I.R.C. $\S 163(\mathrm{~h})(3)(\mathrm{c})(\mathrm{i})$.

${ }^{25}$ I.R.C. $\$ 163(\mathrm{~h})(3)(\mathrm{C})(\mathrm{ii})$. Again, the $\$ 100,000$ limitation also applies to the sum of qualified indebtedness borrowed by married taxpayers.

${ }^{26}$ I.R.C. $\$ 163(\mathrm{~h})(3)(\mathrm{C})(\mathrm{i})$. Two examples demonstrate the interaction of the two statutory restrictions. First, assume the taxpayer has $\$ 500,000$ of acquisition indebtedness on a residence with a current fair market value ("FMV") of $\$ 700,000$. The taxpayer then borrows $\$ 150,000$ with a home equity loan. Under the first restriction, the taxpayer will be allowed to deduct only the interest on the first $\$ 100,000$ of home equity indebtedness or $2 / 3$ of such interest. Second, assume the taxpayer has $\$ 500,000$ of acquisition indebtedness on a residence with a current FMV of $\$ 550,000$. Further, assume the taxpayer has $\$ 75,000$ of home equity indebtedness (borrowed when the residence has a greater FMV). Here, the second limitation operates to limit interest deductions to $2 / 3$ of the interest paid on the $\$ 75,000$. These examples illustrate that deductions can fluctuate with the real estate market by operation of the tax code. 
year. ${ }^{27}$

Taxpayers who own homes and are willing to use them to secure education loans thus receive a subsidy, in the form of a congressional tax expenditure, in excess of that already present in the home mortgage interest deduction which represents money truly borrowed for the home. On the other hand, those taxpayers who do not own their residences, whose residences do not contain enough equity to secure education loans, whose residences already are leveraged up to their fair market values, or who simply do not want to risk their residence by using it as collateral for an education loan will not receive a deduction for the amount of interest paid. As will be shown in section II of this comment, this result is an inequitable deviation from the principles of normative income taxation structure.

\section{Results of $\S 163(\mathrm{~h})$}

1. Undesirable Economic Effects of $\S 163(h)$. Section 163(h) alters the character of borrowing for education expenses. It affects two primary economic considerations: (1) distribution of financial liability on such borrowing, and (2) duty of repayment of the debt. Since most students are not homeowners, any education loan that is to fulfill the deductibility requirements of $\S 163(\mathrm{~h})$ likely will be secured by the parents' qualified residence. Unless the studentchild is made a co-owner of the residence, ${ }^{28}$ the parent must remain liable for repayment of the educational loan to retain the deduction. Even if the student also is made liable for the loan, the parent's qualified residence will serve as security for the debt, and the parents will bear the bulk of the risk of default. If the parent is unable to make future interest payments and the student makes them, the student will be barred from deducting such interest payments, ${ }^{29}$ while the borrower may have to include the amounts paid in her taxable income. ${ }^{30}$

${ }^{27}$ Section 163(h) contains no carryforward provision allowing a future deduction for disallowed amounts of interest paid in the current taxable year. Thus, a taxpayer who does not have enough income in the current taxable year to be able to utilize the deduction, or whose interest payments exceed the limitations of $\S 163(\mathrm{~h})(3)(\mathrm{C})(\mathrm{ii})$, loses the deduction entirely. In contrast, there is a carryforward provision in $\S 163$ (d)(2) for investment interest.

${ }^{28}$ Wealthy parents may begin taking title to residences in the names of their children with the foresight that appreciation in such residences will allow their children to avail themselves of future interest deductions on education loans.

${ }^{28}$ I.R.C. $\$ 163(\mathrm{~h})$ (1). See also I.R.C. $\S 267$ (disallowing interest with respect to transactions between related taxpayers).

${ }^{30}$ Such inclusion appears remote. If the interest payment is below $\$ 10,000$, it will qual- 
This result differs from the pre-1987 apportionment of liability. Prior to the 1986 Code, the student-child could be singly liable on any borrowing for education by using a guaranteed student loan and, under $\S 163(\mathrm{a})$ of the 1954 Code, could deduct any interest paid on such loans. With a guaranteed student loan, the government secures the loan and promises to repay the lender in the event the student defaults. This structure had no tax consequences for the parent. Now, however, the parent and student must decide whether the student should borrow without securing such borrowing with a residence, thus losing the interest deduction, or whether the parent should secure the loan with a residence and risk losing that residence upon default. The decision is not simple because the potential interest deduction can be substantial, yet the risk of losing the residence is real.

The 1986 Code introduces a second economic consideration. The Code structures the repayment of education loans so that the interest deduction in $\S 163(\mathrm{~h})$ is not completely lost. If the borrowing parents repay the loan, they receive the deduction. ${ }^{31}$ However, if the student is to repay the loan secured by her parents' home, a complex series of transactions must be employed to enable her parents to deduct the interest payment. In each repayment period, the child must pay her parents the amount of interest and principal due. This is viewed as a non-taxable gift from the child to her parents under the 1986 Code. $^{32}$ The parent then pays the lending institution and takes a deduction under $\S 163(\mathrm{~h})$ for the amount of interest paid. The child receives no deduction even though her funds were used to make the interest payment.

A student with sole liability for outstanding education loans must employ another method so that her parents can obtain a deduction. Her parents must obtain a home equity loan and then repay the child's outstanding education loans, which may be quite substantial. If such lump sum repayment exceeds the gift tax exemption, ${ }^{33}$ then a gift tax problem may arise. ${ }^{34}$ Nevertheless, the

ify as a tax free gift under I.R.C. $\S 2503$.

${ }^{31}$ Under I.R.C. $\$ 2503(\mathrm{e})$, the parent is allowed to pay unlimited tuition expenses directly to the eductional institution without any gift tax consequences. Other educational expenses, such as books, room, and board, are in theory subject to the gift tax provisions. See Treas.Reg. § 25.2503-6.

${ }^{32}$ See I.R.C. $\$ 7872$. It is possible, though unlikely, that the I.R.S. would take the position that this is a taxable gain to the parent since the child, in essence, is paying a debt.for which the parent is liable. See Joseph Isenbergh, Musings on Form and Substance in Taxation, 49 U.Chi.L.Rev. 859, 874 (1982).

${ }^{33} \$ 20,000$ in the case of married taxpayers filing a joint return. I.R.C. $\S 2502$.

34 Depending on the individual taxpayer, this also may give rise to a unified credit 
parents can deduct the home equity interest and the student can make an annual tax-free gift to her parents to cover the loan payments. These transactions effectively allow the student to repay the education loan while allowing her parents to take the deduction. The attractiveness of having the parents make annual payments with home equity borrowing is minimal because interest is paid twice and produces only one deduction.

It will be much more difficult for the child to both repay the education loan and receive the interest deduction, unless the child owns an appreciated home. If her parents own such a home, they can sell it to the child then lease it back. The child then can secure a home equity loan, make a lump sum repayment of her education loans, and then deduct her home equity interest payments. The sale and lease arrangements could be structured to minimize or eliminate all incidents of taxation.

Regardless of whether these transactions are successful, § 163(h)(3) introduces undesirable complexity into familial relations and what should be relatively straightforward economic transactions. This result frustrates the tax neutrality goals of the 1986 Act.

2. Discriminatory Effects of $\S 163(h)$. Another undesirable effect of $\S 163(\mathrm{~h})$ is unfairness and discrimination against those individuals who borrow for education and do not own a home, or whose homes do not meet the provisions of $\S 163(\mathrm{~h})$. Congress has endorsed a definition of "fairness" so that taxpayers with equal incomes who pursue the same economic activities ideally will pay equal amounts of income tax..$^{35}$ Contrary to this goal, $\S 163(\mathrm{~h})$ produces a situation where two taxpayers with equivalent income income levels likely will pay different amounts of tax. Assume one taxpayer borrows for education securing the loan with her home and a second taxpayer, with the same income as the first, obtains a similar loan without using her home as security. The first taxpayer will pay less tax than the second, because the first taxpayer is entitled to the $\S 163(\mathrm{~h})$ deduction.

Even given the congressional preference for home owning, this inequity is unjustified because education has little to do with homeownership and should not be linked with the homeownership preference. Taxpayers who are unwilling or unable to use a home equity loan to finance their education will be unable to deduct their interest expense, even though education is primarily an in-

problem. See I.R.C. § 2505.

${ }^{35}$ The Blue Book at 7-9 (cited in note 7). 
vestment in human capital, unlike consumption items such as homeownership. Moreover, the many discussions of taxing the imputed rent derived by homeowners indicate that homeownership is most accurately characterized as a consumption item. ${ }^{36}$ Historically, homeowners have not been taxed on the imputed rent of homeownership and have been able to deduct mortgage interest, while renters have not received a corresponding deduction for their monthly rent.

Linking a deduction for education loans to homeownership denies educational opportunity to those at the economic margin of society who are trying to invest in their human capital through borrowing. As the cost of borrowing increases, individuals at the margin may decide it is no longer cost efficient to forego current earnings in order to pursue an education. The cost of borrowing may rise marginally under $\S 163(\mathrm{~h})$ for those non-homeowning borrowers because homeowners will be encouraged to compete for available funds for personal consumption, driving up the cost of borrowing. This result further impedes the realization of educational goals for those individuals who are at the economic margin. ${ }^{37}$

A present value calculation of the costs of pursuing an education illustrates this principle. The relevant equation is:

$[\mathrm{PV}$ (interest deduction) $+\mathrm{PV}$ (future earnings) $]=$ $[\mathrm{PV}$ (forgone earnings) $+\mathrm{PV}$ (tuition expense) $+\mathrm{PV}$ (interest expense $)+\mathrm{PV}($ miscellaneous educational expenses $)]^{38}$

One can draw a number of conclusions from this equation. First, if the left side of the equation exceeds the right, a rational taxpayer would pursue education. Historically, the earnings of college graduates have far exceeded those of high school graduates; ${ }^{39}$ therefore, most individuals, given the opportunity, will opt to pursue higher education. However, as the costs of education continue to rise faster than the earnings of college graduates, one approaches a point where the economic returns of such an education no longer exceeds the costs. At this point, the deductibility of education loan interest expenses will become a decisive factor in whether an individual will pursue higher education. This effect is exacerbated by

36 See id. at 263-64.

${ }^{37}$ See C. Eugene Steuerle, Taxes, Loans, and Inflation: How the Nation's Wealth Becomes Misallocated (1985); Eugene Steuerle, Tax Arbitrage, Inflation, and the Taxation of Interest Payments and Receipts, 30 Wayne L.Rev. 991 (1984).

${ }^{38} \mathrm{PV}=$ present value function.

38 See Department of Education, Center for Education Statistics, Digest of Education Statistics 1987287 (1987)(“Education Statistics"). 
rising interest rates and by an increase in tax rate progression.

Most taxpayers undoubtedly rely on factors other than the deductibility of education loan interest when deciding whether to attend an institution of higher learning. ${ }^{40}$ However, one should not underestimate the economic importance of the deduction for those taxpayers who must borrow to pursue educational opportunities. Those who can recover costs soon after graduation will pursue higher education whether education loan interest is deductible or not. However, as the costs of the education rise, so will the interest expense, thereby extending the cost recovery period. Eventually, this period will exceed that which the taxpayer is willing to endure and she will forego borrowing for higher education. However, if the interest is deductible, the cost recovery period is shortened-an effect of great significance to those taxpayers at the economic margin. Furthermore, assuming borrowed funds are available, taxpayers with external economic burdens, such as the responsibility to support relatives, may be deterred if education loan interest is not deductible. If such a burden is present, the deductibility of interest would be crucial to any decision on whether to pursue higher education.

Section 163(h) thus creates unwarranted complexity and tax bias in taxpayers' economic and education decisions and discriminates between homeowners and non-homeowners. Ironically, these results are the same ones which the 1986 Act sought to reform. ${ }^{41}$ This subsection has not questioned the validity of eliminating the general personal interest deduction. The subsection does contend, however, that Congress erred in effectively eliminating the education loan interest deduction for only some taxpayers. With rising education costs, a growing number of taxpayers must choose between borrowing for education or forgoing an investment in education entirely. ${ }^{42} \mathrm{~A}$ crucial factor in this decision is the deductibility of interest on such loans. ${ }^{43}$

40 Walter W. McMahon, Investment in Higher Education 2-3 (1974)(citing family income as the major determinant).

41 The Blue Book at 6-11 (cited in note 7).

42 See Ray D. Madoff, Back to School After the Tax Reform Act of 1986: Effect of the New Law on Educational Funding, Taxes 570 (Sept. 1987); John R. Kramer, Will Legal Education Remain Affordable, By Whom, and How?, 1987 Duke L.J. 240 (1987).

${ }_{43}$ See McMahon, Investment in Higher Education at 24-25, 40-42, 60-68 (cited in note 40). McMahon states that the four most important factors in making this decision are current income, expected returns, interest rates, and an index of desires for equity in educational opportunity. Id. at 4, 13-19. 


\section{Normative Treatment of Education Expenses}

To fully diagnose the ills of $\S 163(\mathrm{~h})$, one must turn to a baseline normative analysis. Normative study facilitates an evaluation of current tax treatment of certain items and provides direction for tax policy. Congress has expressed a desire to adhere to normative theory wherever possible in order to produce an accurate and equitable income tax system. ${ }^{44}$ Furthermore, in responding to the President's call for fundamental tax reform, the Treasury Department relied exclusively on normative principles when it conceived Treasury I, which provided a foundation for the 1986 Act. $^{45}$

\section{A. Haig-Simons Definition of Income}

Normative income tax theory is based upon an economic definition of income in which income equals all consumption plus the net change in wealth experienced between two points in time. Taxable income is the total amount of consumption and net change in wealth, reduced by the cost of producing the income. ${ }^{46}$

A widely accepted economic definition of income is the HaigSimons concept of personal income. Robert Haig defined income as "the money value of the net accretion to one's economic power between two points in time." ${ }^{47}$ Henry Simons refined Haig's definition as follows:

Personal income may be defined as the algebraic sum of (1) the market value of rights exercised in consumption and (2) the change in the value of the store of property rights between the beginning and the end of the period in question. In other words, it is merely the result obtained by adding consumption during the period to "wealth" at the end of the period and then subtracting "wealth" at the beginning. ${ }^{48}$

14 "The legislative history of the 1974 Act indicates that income is to be defined as closely to economic income as measurement permits." John Karl Scholz, Tax Expenditures, in Joseph A. Pechman, ed., Setting National Priorities: The 1984 Budget 243 (1983).

15 Department of the Treasury, Tax Return for Fairness, Simplicity, and Economic Growth (1984). See Charles E. McLure, Jr. and George R. Zodrow, Treasury I and the Tax Reform Act of 1986: The Economics and Politics of Tax Reform, I J.Econ.Persp. 37 (1987); Joseph A. Pechman, Tax Reform: Theory and Practice, 1 J.Econ.Persp. 11, 15-17 (1987).

16 Justice Stewart recognized this principle in Commissioner v. Tellier, 383 U.S. 687, 691 (1966), stating that "[w]e start with the proposition that the federal income tax is a tax on net income."

47 Robert Murray Haig, The Concept of Income-Economic and Legal Aspects, in Robert Murray Haig, ed., The Federal Income Tax 7 (1921)(emphasis omitted).

${ }^{48}$ Henry C. Simons, Personal Income Taxation: The Definition of Income as a Problem of Fiscal Policy 50 (1938). Simons paraphrased this refinement by stating that personal in- 
The Haig-Simons definition is broad and theoretical, including items which in practice are excluded from the tax base because they are intentional preferences or tax expenditures, ${ }^{49}$ or because they involve administrative or structural distortions ${ }^{50}$ presenting insurmountable obstacles to taxation. ${ }^{\text {s1 }}$ Although the general normative principles of federal income taxation are derived from the Haig-Simons definition of income, Congress is not constrained to follow any one theory of taxation, and in practice the federal income tax system deviates from purely normative principles. In any case, a normative analysis generates valuable insight into how a purely theoretical or ideal system might work.

Under the Haig-Simons definition, net income forms the tax base, and in determining taxable income, the costs of producing income are deductible before the tax rate is applied..$^{62}$ The following subsection applies this principle to show that as an investment in human capital, some portion of the costs of education are properly deductible against the income produced from an investment in education.

\section{B. Proper Treatment of Education Expenses Under the Haig- Simons Definition of Income}

Because education loan interest expenses are a subset of all education expenses, a discussion of the normative treatment of education costs in general is in order. This subsection demonstrates that certain costs of education are investments in human capital which require amortization over the worklife of the taxpayer.

1. Amortization of Education Expenses. The Haig-Simons

come equals consumption plus accretion.

19 For a discussion of tax expenditures, see Analysis of Proposals Relating to Comprehensive Tax Reform, Comm.Prt.No. JCS-3-85, Joint Committee on Taxation, 99th Cong., 1st Sess. 33-34 (1985).

so This second deviation from the Haig-Simons definition will be referred to as "administrative distortions," a phrase suggested by Professor Daniel Shaviro of the University of Chicago Law School.

s1 An example of the former is the tax-exempt status of municipal bonds, see I.R.C. $\S$ 103 , while an example of the latter is the non-taxation of unrealized appreciation.

The latter example is, of course, a distorting principle that is fundamental to our notion of taxation. See Eisner v. Macomber, 252 U.S. 189 (1920), where Justice Pitney reasoned that taxpayers could not be taxed constitutionally under the sixteenth amendment on the "mere appreciation in value" of capital assets; income had to be derived from invested capital. While experts now agree that the realization requirement is not a constitutionally compelled, the requirement continues to be followed for administrative reasons which bar the implementation of an ideal income tax system. See Paul B. Stephan, Federal Income Taxation and Human Capital, 70 Va.L.Rev. 1357, 1360 n.3 (1984).

${ }^{32}$ See Henry C. Simons, Federal Tax Reform (1950). 
model allows deduction of both immediate investment costs and investment costs which require amortization over the asset's useful life..$^{53}$ Under the tax laws, the primary test of whether an item is a deductible capital expenditure or a non-deductible personal expense turns on whether the item has a basis that can be offset against future income, either in computing gain upon disposition or as an immediate deduction. Basis generally represents a taxpayer's cost in acquiring an asset and is subject to adjustments for depreciation. ${ }^{54}$ A portion of an individual's education is an investment in human capital which provides such a basis. ${ }^{55}$ Justice Cardozo generalized that "[r] eputation and learning are akin to capital assets, like the goodwill of an old partnership. For many, they are the only tools with which to hew a pathway to success. The money spent in acquiring them is well and wisely spent."s6

Justice Cardozo implied that such expenses require amortization over the life of the capital asset, in this case the working life of the taxpayer. The taxpayer taking such deductions is the student who benefits from the education and who repays the education loans. Proper normative treatment requires taxing foregone earnings or imputed income "received" while the taxpayer is in school and then amortizing the investment portion of the foregone earnings and the education expenses over her future working life. ${ }^{57}$ Subsequent deductions then should be taken against the income

${ }^{53}$ Amortization of capital costs is an established principle in taxation. See C.I.R. v. Seaboard Finance Company, 367 F.2d 646 (9th Cir. 1966)(allowing amortization of amounts in excess of purchase price found not to be goodwill); Selig v. United States, 565 F.Supp 524 (E.D.Wisc. 1983), aff'd, 740 F.2d 572 (7th Cir. 1984)(allowing amortization of baseball player contracts over players' five-year useful lives under $\$ 167(\mathrm{a})$ ); Treas.Reg. $\$ 1.167(\mathrm{a})-3$ (allowing depreciation of intangible items with reasonably ascertainable useful lives).

s4 See I.R.C. $\S 1011$ et seq.

${ }^{s 5}$ See Section II.B.2.

${ }^{s 8}$ Welch v. Helvering, 290 U.S. 111, 115-116 (1933) (citations omitted). But see Nathaniel A. Denman, 48 T.C. 2504, 2513 (1967) ("Expenditures which are not deductible because personal are not made any less personal or transformed into business expenditures through the mechanics of capitalizing them as cost of an engineering degree so as to supply a basis for claiming a deduction therefor as depreciation"); Huene v. United States, 247 F.Supp. 564 (S.D.N.Y. 1965) (expenses incurred by taxpayer in attending law school were not ordinary and necessary expenses incurred in carrying on business as an accountant so as to be deductible under $\S 162$ of the 1954 Code); Joel A. Sharon, 66 T.C. 515, aff'd sub nom., Sharon v. C.I.R., 591 F.2d 1273 (9th Cir. 1978) (costs of amortizing college, law school, and bar review course held to be non-deductible personal expenses under $\S 262$ of the 1954 Code).

${ }^{37}$ Amortization of education expenses in theory could occur under either I.R.C. $\$ 195$ (capitalization of start-up expenditures) or 263 (capital expenditures). See generally John W. Lee, Start-Up Costs, Section 195, and Clear Reflection of Income: A Tale of Talismans, Tacked-On Tax Reform, and a Touch of Basics, 6 Va.Tax Rev. 1 (1986). 
earned from this investment in human capital. In a purely normative system only a portion of education costs are amortized, however, because education is not entirely an investment in human capital but contains elements of pure personal consumption or cultural enrichment as well.

2. Education: An Investment in Human Capital. The deductibility of education loan interest expenses under normative income tax theory depends upon the characterization of at least a portion of education as an investment in human capital. ${ }^{58}$ Professor Stephan defines human capital:

Human capital, in economic terms, is equivalent to the present value of the flow of future satisfactions that an individual can command in the course of his life. Some portion of this capital constitutes endowment, the biological and social inheritance that accompanies a person into the world. The remainder is acquired through individual action, such as education, on-the-job training, migration, and health care, or stems from exogenous changes such as technological or social transformation..$^{\text {se }}$

Under Professor Stephan's definition of human capital, individuals may "acquire" or increase human capital through education. Education has two potential results: (1) it can increase a taxpayer's personal cultural enrichment, raising the level of future non-taxable satisfactions, and (2) it can increase a taxpayer's earning capacity. These results form the foundation for normative tax treatment of education expenses under the Haig-Simons definition of income.

The first result, as a general principle, represents a consumption item which does not produce a greater level of taxable income and, on normative grounds, does not merit a deduction. In many respects, the return on such an investment in education is purely personal, enriching the investor culturally but not producing a taxable benefit.

ss For analysis of the problems inherent in defining human capital see Stephan, 70 Va.L.Rev. at 1364 (cited in note 51). See also Alan Gunn, The Case for an Income Tax, 46 U.Chi.L.Rev. 370, 382 (1979)(taxing an individual's earning potential may place "an unacceptable restriction on freedom"). On the human capital concept in general, see Gary S. Becker, Human Capital: A Theoretical and Empirical Analysis with Special Reference to Education (2d ed. 1975); Elchanan Cohn, The Economics of Education 13-20 (1979).

${ }^{58}$ Stephan, 70 Va.L.Rev, at 1358-1359 (cited in note 51)(footnote omitted). See also Theodore Schultz, Investment in Human Capital, 51 Am.Econ.Rev. 1 (1961)("Much of what we call consumption constitutes investment in human capital. Direct expenditures on education, health, and internal migration to take advantage of better job opportunities are clear examples."). 
It would be inaccurate to conclude, however, that the investment is entirely personal in nature. Individual investment in education also produces rewards to society. Education increases the intelligence of the citizenry, which improves the democratic process. $^{.0}$ In addition, society benefits from those individuals whose education induces them to pursue public interest work after their schooling. Since public sector jobs generally pay less in economic terms than comparable private sector jobs, the individual generally receives a lesser economic return. The educated individual may be compensated for the lower economic return by a greater sense of cultural satisfaction. The nation obtains an increased benefit from this labor, therefore, at a cost below similar work purchased in the private arena. Clearly, an individual may benefit personally from time spent in public service if she later enters the private sector; nevertheless, society benefits from the individual's earlier investment in education in the form of high quality public service at reduced cost.

More important for our analysis, however, is the second of the two results: an investment in education generally leads to greater taxable income. Like any capital investment, individual investment in education produces an economic return of present value in excess of the present value cost of the investment. ${ }^{61}$ For the average individual, an investment in education produces a return, in the form of a future income stream greater than it would have been without such an investment. The total cost of the education comprises (1) the forgone earnings ${ }^{62}$ the student bypassed to pursue an education, (2) tuition, (3) books and supplies, and (4) the cost of financing any borrowing to pay for such education. ${ }^{63}$ This aggre-

BO Cohn, Economics of Education at 32-33 (cited in note 58).

61 See Education Statistics at 286-88 (cited in note 39).

${ }^{62}$ For many students, forgone earnings may be inconsequential. No matter how small such earnings are, however, they must enter into the calculation, especially for those weighing the costs of pursuing an education against current earnings. Under purely normative theory, foregone earnings (or imputed income) require taxation. For example, a college student would be taxed on the imputed income she receives while attending school. See Stephan, 71 Va.L.Rev, at 1368 (cited in note 51). However, the practical difficulties with taxing imputed income render such taxation unlikely.

${ }^{63}$ Under I.R.C. \& 163(h), homeowning taxpayers can deduct the interest expense of borrowing against their home to pay any education expenses. This option also extends to interest on similar loans used to finance any personal consumption items, such as automobiles or living expenses. Superficially, these items, when used by a student, may appear to be a "cost" of seeking an education; however, they are more accurately characterized as consumption items and would not be deductible on normative grounds. Furthermore, other Code sections contradict $\S 163(\mathrm{~h})$ 's generous treatment of consumption items. Section 127 (c)(1) specifically excludes meals, lodging, and transportation from the definition of em- 
gate figure must then be apportioned into its component parts, reflecting cultural enrichment and investment in human capital. The analysis focuses on the extent to which the return on such an investment is a non-taxable return in the form of pure cultural enrichment or is taxable income in the form of enhanced earnings. For the majority of taxpayers, the actual result is a mixture of the two, with enhancement of the taxpayer's earning capacity tending to be directly proportional to the educational level attained..$^{64}$

Education costs should be deductible even if one assumes that education serves only to identify those taxpayers with greater genetic and social endowments. If one views education as an identifier which adds nothing of value to the taxpayer, one might conclude that education is purely an exercise in consumption. This view assumes that those taxpayers who pursue education would earn equal or greater amounts without an education. While the applicability of this argument at first appears limited to those fields which, unlike law and medicine, are not regulated monopolies requiring higher education for admittance, one can argue that taxpayers entering these regulated fields would earn equal or greater amounts if they entered other fields which do not require higher education. This general line of reasoning fails, however, because the identifying function of education alone leads to enhanced earnings capacity. Even if the process of education (classes, exams, studying) is not directly related to earnings, it nonetheless increases the earnings value of the taxpayer's human capital because it identifies those taxpayers with greater genetic or social endowments. Thus, the investment in an "identifying" education is a cost of enhancing earnings capacity and requires amortization. It is of no consequence that education may be of little or no objective value, as long as it serves an identification purpose which results in a higher earnings potential. Because education expenses are a cost of producing increased income, the investment portion of education costs are properly amortized and deducted according to normative theory.

3. Reasons to Use Human Capital Theory. The argument for allowing deductions for education expenses relies upon the accept-

ployers' non-taxable "educational assistance." See also $§ 117(\mathrm{~b})(2)$, which provides that the deduction for "qualified tuition and related expenses" includes only tuition, fees, books, supplies, and equipment required for courses of instruction.

64 See Education Statistics at 286-88 (cited in note 39). See also Survey Finds Outlook on Jobs is Good for College Graduates, N.Y.Times at 11, col. 5 (Dec. 1, 1987)(citing Michigan State University study). 
ance of the human capital theory. Critics of human capital theory cite the moral difficulty society might have in valuing taxpayers' useful lives and depreciating human assets. ${ }^{65}$ Opposition to applying human capital theory stems from the perception that treating human capital like tangible capital, such as machines and buildings, dehumanizes people. Any moral squeamishness ought to yield, however, to the positive consequences of allowing taxpayers depreciation deductions for education expenses. ${ }^{66}$ A deduction gives taxpayers greater resources to invest in their human capital and, by reducing tax bias against investment, makes such options as attractive as investment in non-human capital. Some of the money otherwise used to pay taxes is freed for more productive use by the taxpayer. These factors combine to facilitate individual accumulation of human capital through the pursuit of higher education, ultimately resulting in greater individual freedom.

Moreover, Congress implicitly subscribes to the view that education is an investment in human capital: Congress grants corporations a deduction for employee education expenses under $\S 162$ and grants employees a deduction for education related to the maintenance of their present jobs under Treasury Regulation 1.162-5. These provisions rely on the premise that specific education expenses equal business expenses for certain taxpayers. While these deductions thus are viewed as an extension of the corporate deduction, these rules implicitly acknowledge the validity of applying human capital theory to education expenses. The human capital concept also underlies the depreciation deductions taken under $\S 167$ (a) by professional sports teams for amortization of the value inherent in their players' contracts. ${ }^{87}$ These examples demonstrate Congress' willingness to follow human capital theory in other areas of income taxation. In the context of education loan interest expenses, fairness demands applying human capital theory to all

${ }^{35}$ See Stephan, 70 Va.L.Rev. at 1364-1366 (cited in note 51) (summarizing the many arguments against taxing human capital).

${ }^{68}$ In examining taxation of human capital, Professor Stephan refutes arguments against such a proposal advanced by Professors Kelman and Warren. Stephan, 70 Va.L.Rev. at 1365-1366 nn.12 and 14 (cited in note 51). Stephan first claims that our present tax system already taxes human earning potential indirectly. Second, he says that taxing human earning potential does not violate "personhood" any more than does our system of damages under contract law. Finally, he argues that any images of slavery that the human capital concept may invoke are clearly alarmist and inaccurate. Through individual action and investment in human capital, taxpayers expand their personal economic freedom, not enslave themselves. See also Schultz, 51 Am.Econ.Rev. at 2 (cited in note 59); Lester Thurow, Investment in Human Capital 124 (1970).

${ }^{87}$ See Selig, 740 F.2d 572. 
taxpayers. $^{68}$

\section{A Practical Legislative Proposal for Modification of § 163(H)}

This section will argue that the expense of borrowing for education should be deductible against ordinary income when the interest expense is paid, in order to ameliorate the burden imposed by denying the deductibility of most education expenses. This proposal represents a compromise solution to the difficult practical problems raised by a purely theoretical approach. Subsection A describes in more detail the proposed legislative solution; subsection $B$ then justifies the proposal.

\section{A. Legislative Solution}

The following proposal follows a more normative course than $\S$ 163(h). It relies upon the conclusions reached in section II and makes a deduction for education loan interest equally available to all itemizing taxpayers. Under this proposal, the taxpayer calculates her loan interest deduction in the following manner. First, the taxpayer computes the total interest due over the repayment period on her loans. This ordinarily will be done during the first taxable year after she has completed her education. ${ }^{69}$ The lender easily can notify the taxpayer of the total interest due and of the length of the repayment period. Second, the taxpayer amortizes the total interest due over the repayment period to arrive at the proper amount of deductible interest for each taxable year, an-

${ }^{68}$ The human capital concept, though readily accepted in the economic and academic communities, has received little attention by Congress, the courts, and the IRS in interpreting our tax laws. Stephan, 70 Va.L.Rev. at 1357 (cited in note 51). Nevertheless, some courts use it in the marital property area. See, e.g., Moss v. Moss, 80 Mich.App. 693, 264 N.W.2d 97 (1978) (amount of alimony awarded wife represented her contribution toward husband's medical degree); In re Cropp, 5 Fam.L.Rep. (BNA) 2957 (Minn.Dist.Ct. 1979) (award of gross alimony would be justified on theory of wife's property interest in educated spouse's future earnings). See generally Joan M. Krauskopf, Recompense for Financing Spouse's Education: Legal Protection for the Marital Investor in Human Capital, 28 Kan.L.Rev. 379 (1980); Note, Equitable Interest in Enhanced Earning Capacity: The Treatment of a Professional Degree at Dissolution, 60 Wash.L.Rev. 431 (1985). But See In re Marriage of Graham, 194 Colo. 429, 574 P.2d 75 (1978) (holding that an M.B.A. degree acquired during marriage is not property subject to distribution upon divorce).

Note also that race horses are commonly amortized and depreciation deductions are taken over their worklife. See F.C. McDougal, 62 T.C. 720 (1974).

${ }^{69}$ The educational institution must fulfill the requirements of I.R.C. $\$ 170$ (governing organizations to which deductible contributions may be made) and the regulations prescribed thereunder. The Treasury publishes a list of all educational organizations which satisfy this provision. 
other calculation which the lender can provide. In essence, this method forces the taxpayer onto the cash receipts and disbursements method of accounting; the amount of each deduction exactly matches the interest paid in each taxable year. The deduction is taken against ordinary income of the taxpayer, as such income is the return on the taxpayer's investment in education.

Early repayment of the education loan would result in accelerated deductions of the interest. Refinanced amounts would follow a similar route to deductibility. Carryforward provisions could be implemented to protect those taxpayers who are unable to fully utilize deductions. Furthermore, taxpayers who borrow for both college and professional school can preserve interest deductions for future taxable years when the return on their education investment actually accrues.

\section{B. Interest Expenses and Normative Theory}

The proposed deduction for interest expenses offers an accurate, simple, and administrable treatment of education expenses. The solution compensates for the practical difficulties that bar the deductibility of the bulk of education investment expenses by allowing a deduction for both the investment and consumption portions of the interest expense. The inclusion of the consumption portion of the education interest expense in the amount deducted is not an error but a useful remedy for other departures from normative theory which also enhances administrative simplicity for both the taxpayer and the government. This proposal more closely follows a normative course than does the denial of interest deductibility to the majority of taxpayers currently found in $\S 163(\mathrm{~h})$.

This section's proposal for deducting education loan interest thus is a compromise that ameliorates the denial of the education expense deduction while avoiding the administrative difficulties inherent in efforts to separate education expenses into consumption and capital portions. Although pure normative theory permits the deduction only of the capital portion of this cost, allowing the deductibility of the entire interest expense is justified on two grounds. First, proper normative deductibility of the bulk of education costs is highly unlikely to occur. Second, allowing a deduction for both the consumption and investment portions of the interest expense avoids useless complexity and cost.

1. Impracticality of Normative Amortization for the Bulk of Education Expenses. Both administrative and economic impediments bar the deductibility of the bulk of education expenses. On the administrative level, normative treatment of all education ex- 
penses is unlikely because of the difficulty in computing the proper depreciation deductions. One cannot accurately predict the length of each taxpayer's working life or the amortization period. Even if one satisfactorily could approximate the taxpayer's work life, it is impossible to quantify either the fraction of human capital investment or cultural enrichment that together comprise all education expenses. Therefore, amortization rates are impossible to calculate with precision on an individual basis.

One could overcome the difficulty of predicting the length of an individual taxpayer's life by defining the amortization period as the average working life of all taxpayers at a given level of educational attainment. ${ }^{70}$ However, using statistics on the average length of working life would be somewhat unfair to those taxpayers who stopped working before the average period and an undue benefit to other taxpayers who worked beyond the average. Additionally, most taxpayers earn more in the years closest to retirement, so one could argue that a greater portion of the educational investment should be attributed to those years rather than to earlier years. Thus, it is unclear that the straight-line method of amortization provides a reasonable compromise. ${ }^{71}$

Even if one could approximate the amortization period, it is impossible to break down education costs on either an individual or aggregate level. For example, some students rarely attend class and do minimal amounts of work, spending the bulk of their time consuming available leisure time, while other students may work tirelessly to increase their human capital. A student's intensity or dedication, however, may have little to do with economic motive or with the level of economic return achieved. Moreover, it may seem unfair to allow a deduction to a student attending an expensive private institution who only goes to school for cultural enrichment or consumption and then works in a job that does not call upon

${ }^{70}$ One can find the exact period for each taxpayer in a comprehensive Labor Department study. The average length of working life is between thirty-five and forty years for most male college graduates, and between twenty-five and thirty years for most female college graduates. Department of Labor, Bureau of Labor Statistics, Worklif e Estimates: Effects of Race and Education, Bulletin 2254 14, 20 (1986). The study gives worklife expectancies for men and women by years of schooling completed, age, and whether currently active or inactive in the labor force.

71 But see Walter J. Blum, Accelerated Depreciation: A Proper Allowance for Measuring Net Income?!!, 78 Mich.L.Rev. 1172 (1980)(attacking the view that accelerated depreciation upholds tax neutrality in the context of machinery and buildings). Professor Blum's reasoning could be extrapolated to the human capital context and might support a straightline method here. Indeed, portions of the Code use straight-line depreciation. See I.R.C. $\S$ 168 (accelerated cost recovery system); $\$ 57$ (b) (straight-line depreciation of intangibles). 
anything she might have learned in school. It is impossible to determine on an individual basis what portion of that individual's success is attributable to an investment in education and what portion derives from unrelated factors.

Moreover, economic and political pressures provide an independent reason for believing that the Code will not allow amortization of the bulk of educational expenses along proper normative lines. Throughout the tax field, numerous items beg for normative treatment but will never receive it because of the prohibitive cost to the Treasury of allowing their deductibility. The deductibility of educational costs is among these items. Approximately $\$ 21$ billion is spent on higher education tuition and fees by students. ${ }^{22}$ If even one-fifth of this were deductible by taxpayers in the 28 percent tax bracket as an investment in human capital, it potentially could reduce government revenues by well over $\$ 1$ billion annually. ${ }^{73}$ Total federal support for education currently exceeds $\$ 63$ billion annually. ${ }^{74}$ Moreover, society currently feels that individuals and families who can afford to save for education should pay for their educations without government subsidization. ${ }^{75}$ This view, coupled with the prohibitive cost to the Treasury of allowing such a broad deduction, renders it unlikely that Congress will implement one, even if justified on normative grounds.

2. Normative Treatment of the Cost of Borrowing for Education. This comment proposes that the entire interest expense of education borrowing be deductible because it will diminish the negative effects of denying a deduction for all education expenses, will enhance conformity of the tax code to normative principles, and is not prohibitively costly. Since some percentage of education is an investment in human capital and the cost of this investment generally far exceeds the interest expense of borrowing for education, the full amount of interest expenses should be deductible as they are paid.

As is true of all loans, an education loan is not treated as taxa-

${ }^{72}$ Education Statistics at 228 (cited in note 39 ).

73 The calculation is: $(\$ 21,000,000,000)(1 / 5)(28 \%)=\$ 1,176,000,000$.

${ }^{74}$ Education Statistics at 280 (cited in note 39 ). The $\$ 63$ billion includes both direct and indirect government expenditures for all levels of education.

${ }^{75}$ Recently, proposals encouraging taxpayers to save for education have proliferated at both the federal and state levels. These plans usually take the form of "college bonds," "educational savings bonds," or "tuition futures." The former two proposals involve the sale of government bonds to taxpayers with interest accruing tax-free-paralleling the current treatment of tax-free municipal bonds. See Allan Murry and Joel Davidson, White House Backs Tax-Free Bonds for Education, Wall St.J. at 44, col. 2 (Jan. 5, 1988). 
ble income of the student when borrowed. ${ }^{76}$ Under conservative normative analysis, however, the investment portion of the education expenses financed by the loan should be amortized over the future work life of the student. Theoretically, the amount of amortized interest will mirror the proportion of underlying principal that is attributed to an investment in human capital. ${ }^{77}$ Although such calculations are impossible to make accurately on an individualized basis, one can overcome this inaccuracy and reach a normatively justifiable result.

Treatment of education as a capital investment raises two familiar questions: (1) What fraction of the interest expense should be attributed to investment and increased earnings capacity?, and (2) Over how many years should the interest expense of borrowing for education be amortized? The former question is easily answered since the bulk of education expenses probably will never receive proper normative deductibility. The non-deductibility of the entire principal more than offsets the consumption portion of the interest expense. ${ }^{78}$ Therefore, the entire interest cost is properly deductible.

Determining the number of years over which to amortize the interest is more difficult. The interest cost of an education is most accurately matched with a taxpayer's early earning years. Initially, an employee is hired for her education and her potential contribution to her employer's economic success. Thus, earnings in the years immediately following graduation account for much of the present value of the education investment. As the taxpayer ages, the economic value of education obtained many years earlier, while still important, diminishes, and any increased earnings tend to reflect experience and job skills acquired while working as well as education.

${ }^{76}$ See Marvin A. Chirelstein, Federal Income Taxation 48 (4th ed. 1985). Parents borrowing to finance their child's education are similarly treated. It is a settled tax principle that loans are not income because of the duty to repay those loans. As a corollary, loan payments are not deductible.

${ }^{77}$ For a discussion of capitalization of interest expenses, see Surrey, Pathways to Tax Reform at 261-64 (cited in note 9).

${ }^{78}$ Professor Klein proposes that investment and consumption are interchangeable since assets can be sold to finance consumption or consumption can be constrained to finance investment. The ability to borrow allows avoidance of this principle. See generally, William A. Klein, Borrowing to Finance Tax-Favored Investments, 1962 Wisc.L.Rev. 608. Applying this argument to education results in the position that students should forego consumption to avoid borrowing to finance education. This theory disintegrates when applied to education, however, because students borrow amounts far in excess of their consumption levels. Investment and consumption are not fungible for most students. This theory may have greater applicability to the family unit of taxation rather than the individual unit. 
It is clear, therefore, that straight-line depreciation of the cost of an investment in education over a taxpayer's working life is unsatisfactory, especially since the work histories of individual taxpayers are highly unpredictable. A more desirable depreciation schedule amortizes the interest expense over the repayment period specified by the terms of the loan itself. This results in a satisfactory matching of the borrowing cost of the investment in education with its return in the years immediately following graduation since, on average, education loans are repaid over ten years. ${ }^{79}$ Even if one borrows the full cost of education so as to maximize the interest expense and to produce the largest deduction possible, the repayment plan will automatically spread the deduction over ten years. Alternatively, if a student borrows a lesser amount, the interest cost will be lower and spread over a shorter time period. In each of these cases, the built-in repayment plan provides an accurate matching of the cost of the loan with the return on the education investment. When the interest cost is smaller, the return attributable to that cost also is less, so the repayment and the smaller deductions occur over fewer years.

In addition, a taxpayer's ability to repay the loan is a natural constraint on deductions. If the taxpayer receives sufficient return on her investment, enabling her to shorten the repayment period, the interest cost is reduced and the taxpayer receives a smaller interest expense deduction. If the taxpayer receives a lower than expected return from her investment and earnings have not been enhanced, she will either default on the loan or repay the loan with unearned income from another source. There will be no interest to deduct if the taxpayer defaults on the loan and no earned income from which to deduct interest if she must rely on unearned income to repay it.

If the taxpayer invests in education and receives little or no return in the form of enhanced earnings capacity and she can pay the interest charges with earnings from a job that is unrelated to her education, should the taxpayer still receive a deduction for the interest paid? Yes, because the taxpayer risked investing in education. Even though the investment failed to pay off, the taxpayer still deserves a deduction. A positive return is not a prerequisite to

79 The ten year average repayment period is typical of a federally guaranteed student loan. Department of Education, Statistical Analysis Department (telephone conversation with Department Analyst). The Department of Education divides this period into 2.5 years in college, a 6 month grace period, and a 7 year repayment period. The Department of Education relies on these figures for internal budget calculations. 
deductibility and, in any event, policing a taxpayer's intention in pursuing education is impossible. One can assume that most taxpayers do not bear the costs of education merely to avoid taxes.

In summary, deducting interest expenses when paid results in a satisfactory matching of return on the investment in education with the cost of producing that return and should be allowed since the income is taxed as it is produced. Making education loan interest deductible when paid also facilitates administration of the deduction; ${ }^{80}$ such a deduction would add only a minimal level of complexity to returns. Some scholars have argued that a universal interest deduction should be available; if one accepts their argument then the case for this limited deduction for education loan interest becomes all the more powerful. ${ }^{\text {s1 }}$ Such a limited deduction is tax neutral since most taxpayers will not borrow for education merely to receive the tax benefit. Finally, this treatment avoids undesirable costs associated with implementing, applying, and enforcing a complex proportional deduction system that attempts to separate consumption from capital investment.

A criticism of allowing the deduction of education interest expenses and education expenses in general is that such a deduction would place an additional burden on taxpayers who do not have to borrow for education or those taxpayers who do not invest in education. Even if this criticism is valid, it is underinclusive because many deductions are only available to those who pursue particular investments. Moreover, it does not undercut the proposition that interest expenses should be deductible as a cost of producing income. Education costs are plainly among the individual investments which merit deduction of interest expenses as they are paid.

${ }^{80}$ Section 163(a) of the 1954 Code (now repealed) testifies to the administrability of such an interest deduction.

${ }^{81}$ See Alan Gunn, Is an Interest Deduction for Personal Debt a Tax Expenditure?, 1 Can.Tax. 46 (1979). But see Calvin H. Johnson, Is an Interest Deduction Inevitable?, 6 Va.Tax Rev. 123 (1986). In reaching a contrary result Professor Johnson outlines the various theories underlying the concept of the universal interest deduction. Briefly, they are (1) that individuals with and without capital should be taxed equally; (2) that lenders and borrowers form an inherent investment partnership and the taxation of the lender on the interest received requires matching deductibility for the borrower; (3) that all cash is fungible and matching is impossible so it is useless to attempt rationalizing the deductibility of some interest and the non-deductibility of other interest; and (4) that the deductibility of interest provides a valuable reference point for taxation. Id. at 124-25. 
C. The Proposed Legislative Solution Avoids the Inequities of $\S$ 163(h)

As discussed in sections I and II, $\S 163(\mathrm{~h})$ deviates from the normative theory assumed by this comment's legislative solution. The crucial distinction between the proposed solution and § 163(h) is the tax neutrality of the former that is noticeably absent in the latter. First, if all taxpayers, however they structure their educational borrowing, receive the proposed deduction, they will be more likely to make educational investment decisions uninfluenced by federal tax considerations. Second, the proposed solution promotes fairness because all taxpayers can deduct education loan interest, whereas $\S 163(\mathrm{~h})$ unfairly discriminates between homeowners and non-homeowners. Third, the proposed solution results in greater simplicity for both taxpayers and the government since it requires taxpayers to deduct their education loan interest payments as they are made, in contrast to $\S 163(\mathrm{~h})$, which may compel taxpayers to enter complex transactions in order to deduct educational interest expenses. Fourth, the proposed solution does not require that the taxpayer secure borrowing for education with a residence, as does § 163(h). Fifth, the proposed solution more closely approximates a normative model to taxation because it allows a deduction only for education loan interest expenses, while $\S 163(\mathrm{~h})$ gives a general deduction to homeowners for personal interest expenses.

\section{Conclusion}

This comment has proposed that interest on loans for educational purposes should be deductible equally by all taxpayers who borrow to invest in their human capital by pursuing education. Congress should not preserve a politically expedient tax policy which sacrifices investments in human capital-one of our most valuable resources-in its search for revenues. The normative theory of taxation requires that the interest expense of borrowing for education be deductible. This deduction should not be linked with homeownership, but rather to individual investment in human capital.

If $\S 163(\mathrm{~h})$ is not amended the nation may suffer both economically and culturally. Fewer individuals from non-homeowning families, primarily those of disadvantaged economic groups, will realize their full potential because they will decide that the cost of borrowing to invest in education is not justified by the return on such an investment. These individuals will pursue a course which is rational on an individual basis but costly for the nation as a 
whole. ${ }^{82}$ Our tax laws ought to encourage, not discourage, the pursuit of education and individual investment in human capital.

82 Because an equally available interest deduction creates a more highly educated populace, over time, it will stimulate greater growth and productivity thus increasing the GNP and the nation's tax base, resulting in a future net gain to the government. See generally The Blue Book at 6 (cited in note 7) ("The sharp reductions in individual and corporate tax rates provided by the Act and the elimination of many tax preferences will directly remove or lessen tax considerations in labor, investment, and consumption decisions"). 